\title{
NUTRITIONAL STATUS OF PATIENTS WITH TUBERCULOSIS ATTENDING AT TERTIARY MEDICAL CENTER IN BANGLADESH
}

\author{
MOHAMMAD FERDOUS UR RAHAMAN ${ }^{1}$, JANNATARA SHEFA ${ }^{2}$, MANOS KUMAR MANDAL ${ }^{3}$, MD. RAFIQUL ALAM ${ }^{4}$
}

\begin{abstract}
:
Background: Tuberculosis (TB) is a common communicable disease in Bangladesh. Treatment of $T B$ sometimes depends on nutritional status of the patient. Both in developed and developing countries $T B$ has been found to coexist with malnutrition among patients at the beginning of treatment. So it would be very important to evaluate the nutritional assessment of a patient before starting treatment. If malnutrition exists in a patient of TB than nutrition supplementation can play an important role in improving the disease condition to reduce further morbidity and mortality.

Method:It was a descriptive study, conducted on eighty-seven adult TB participant attending at medicine department, Bangabandhu Sheikh Mujib Medical University (BSMMU), where nutritional status (Body-Mass Index or BMI) was measured by keeping records of patient's height in meters and weight in kilogram.

Result: A total 87 participants were included in this study where 45 (52 percent) were males and 42 (48 percent) were females. Most of the participants were healthy 56 percent $(n=49)$ participants. However, under-nutrition was present in 36 percent $(n=31)$ participants and over-nutrition were only 8 percent $(n=7)$. Most of the participant takes more than three meals 54 percent $(n=47)$ participants. However, three meals were taken by 45 percent $(n=39)$ participants and two meals were taken only 1 percent $(n=1)$.

Conclusion: In this study almost $36 \%$ participants of tuberculosis were in under-nutrition. So Nutrition supplementation could be needed in improving the disease condition to reduce further morbidity and mortality. On the other hand large scale study should be needed for taking proper steps to know the overall situation of the country.
\end{abstract}

Key words: Tuberculosis, Nutrition Status, Malnutrition.

Received: 05 November 2018

Accepted: 21 April 2019

DOI: https://doi.org/10.3329/bjmed.v30i2.41530

\section{Introduction}

Malnutrition in tuberculosis (TB) patients is common in both developed and developing countries. ${ }^{1-4}$ TB and malnutrition are major public health problems in Bangladesh where Bangladesh still ranks among the top ten countries in the world with the highest TB burden. ${ }^{5}$ Here in Bangladesh, around 186 people die of TB every day and around 68000 per year. ${ }^{6}$ In 22 high tuberculosis-burden countries Bangladesh is one of them. The incidence, prevalence and mortality estimates for tuberculosis (TB) are 225/100 000, 434 per 100000 and 45/100 000 respectively and $1.4 \%$ statistics of multidrug resistant cases. ${ }^{7}$ For TB patients nutrition is the key point. TB treatment may be complicated when malnutrition also coexists in that particular patients. TB has been found to coexist with malnutrition among participants at the beginning of treatment in both developed and developing countries. ${ }^{8,9,10,11}$ Malnutrition is frequently observed in patients with pulmonary TB. Several studies

1. Associate Professor, Department of Internal Medicine, BSMMU, Dhaka

2. Research Medical Officer, Institute of pediatrics Neurodisorder and Autism in Children, BSMMU

3. Resident (Internal Medicine), Phase-B, Department of Internal Medicine, BSMMU

4. Associate Professor, Department of Internal Medicine, BSMMU

Address of Correspondence: Dr. Mohammad Ferdous Ur Rahaman, Associate Professor, Department of Internal, Medicine, BSMMU, Mobile: 01711615865, E-mail: ferdousbsmmu@yahoo.com

Bangladesh J Medicine 2019; 30 : 53-57 
reported that patients with active pulmonary TB are malnourished, as indicated by reductions in the level of visceral proteins, anthropometric indexes and micronutrient status 12,13 Nutrition support is necessary for malnourished TB patients. Nutrition risk assessment is important in providing nutrition support. Even, in Bangladesh we don't have much information about the nutritional situation of TB patient to formulate nutrition intervention. This study was designed to fill-in this knowledge gap.

\section{Methodology}

This study was a cross-sectional study conducted on eighty-seven adult TB patients were taken from medicine department, Bangabandhu Sheikh Mujib Medical University (BSMMU), where the participants regularly visit for the treatment. At first Eighty-seven patients with suspected pulmonary tuberculosis were taken for pathological test. The diagnosis of pulmonary TB was made on the basis of symptoms and the presence of $M$. tuberculosis. Then by face to face interview a semi-structured questionnaire filledup where height of the patient's was recorded in meter and weight was recorded in kilogram. Medical officers were played as data collector of this study. Patient age ranged from 18 to 91 years (mean, 64.9 years). This study was approved by the institutional review board of Bangabandhu Sheikh Mujib Medical University, Shahbagh, Dhaka. Data variables were collected from indoor and outdoor of Department of Internal Medicine, Bangabandhu Sheikh Mujib Medical Universityfrom January 2017 to December 2017 in relation to the objectives of the study.

After coding and editing, data were analyzed by using Statistical Package for Social Science or SPSS (version 21 IBM). According to variable and mean, standard deviation were calculated and presented by table. The BMI will be calculated as body weight $(\mathrm{kg})$ divided by height in meter square $\left(\mathrm{BMI}=\mathrm{wt}(\mathrm{kg}) /\right.$ height $\left.\mathrm{m}^{2}\right)$. BMI $\leq 18.5 \mathrm{~kg} / \mathrm{m} 2$ taken as cut-off points for malnutrition(1. Severe Under nutrition (BMI: <16) ,2. Moderate Under nutrition (BMI: 16-17), 3. Mild Under nutrition (BMI: 17-18.4), 4. (BMI: 18.5-24.9), 5. Over weight(BMI: 2529.9), 6. Moderately Obese (BMI: 30-34.9), 7. Severely Obese (BMI: 35-39.9), 8. Morbid Obese (BMI : >40)

\section{Result}

Age distribution of participants are shown inTable- 1 which represents 20 percent participant were ' $14-20$ years' ( $\mathrm{n}=18)$ and ' $21-35$ years' (44 percent, $n=39)$. On the other hand, '36-50 years' (21 percent, $n=19)$ and '51 above' (15 percent, $n=24)$.
Table-1

Age of participant

\begin{tabular}{lc}
\hline Age of Participant & Percent (n) \\
\hline $14-20$ years & $20(18)$ \\
$21-35$ years & $44(39)$ \\
$36-50$ years & $21(19)$ \\
51 years \& above & $15(24)$ \\
\hline
\end{tabular}

Table II shows that among 87 participants, 45 (52 percent) were males and 42 (48 percent) were females.

Table-II

Sex of Participants

\begin{tabular}{lc}
\hline Sex of Participants & Percent (n) \\
\hline Male & $52(45)$ \\
Female & $48(42)$ \\
\hline
\end{tabular}

Most of the participants were married (76 percent, $\mathrm{n}=66)$ and unmarried were (24 percent, $\mathrm{n}=21)$.

Table-III

Marital Status of participant

\begin{tabular}{lc}
\hline Marital Status & Percent (n) \\
\hline Married & $76(66)$ \\
Unmarried & $24(21)$ \\
\hline
\end{tabular}

Findings related to education of patents are presented in Table-IV. Data show that illiterate was 11 percent, $(n=10)$, primary was 21 percent, $(n=18)$, secondaryhigher secondary was 54 percent $(n=47)$ and graduation $\&$ above was 14 percent $(n=12)$.

Table-IV

Education of participant

\begin{tabular}{lc}
\hline Participant's education level & Percent (n) \\
\hline Illiterate & $11(10)$ \\
Primary & $21(18)$ \\
Secondary-Higher secondary & $54(47)$ \\
Graduation \& above & $14(12)$ \\
\hline
\end{tabular}

Table-V reveals that 23 percent $(n=20)$ participants were student, 21 percent $(n=18)$ were house wife, 14 percent $(n=12)$ were service holder, 11 percent $(n=10)$ were day labor, 9 percent $(n=8)$ were doing business, 8 percent $(n=7)$ doing agriculture and 14 percent $(n=12)$ had other occupation. 
Table-V Occupation of participant

\begin{tabular}{lc}
\hline Occupation & Percent (n) \\
\hline Agriculture & $8(7)$ \\
Business & $9(8)$ \\
Day labor & $11(10)$ \\
Service holder & $14(12)$ \\
Student & $23(20)$ \\
House wife & $21(18)$ \\
Others & $14(12)$ \\
\hline
\end{tabular}

Monthly income of participantis displayed in TableVI. Most of the participant's monthly income $(<20000$ taka) were (59 percent, $n=68),(20000-39000$ taka) were (25 percent, $n=29)$ and (40000-59000 taka) were (3 percent, $n=3)$.

Table-VI

Monthly income of participant

\begin{tabular}{lc}
\hline Monthly income(in Taka) & Percent (n) \\
\hline$<20000$ & $68(59)$ \\
$20000-39000$ & $29(25)$ \\
$40000-59000$ & $3(3)$ \\
\hline
\end{tabular}

Table-VII shows that own house were present in 44 percent $(n=38)$ participants. However, rented house were present in 54 percent $(n=47)$ participants and homeless were only 2 percent $(n=2)$.

Table-VII

Housing status of participant

\begin{tabular}{lc}
\hline Housing status & Percent (n) \\
\hline Own house & $44(38)$ \\
Rented house & $54(47)$ \\
Home less & $2(2)$ \\
\hline
\end{tabular}

Table-VIII shows that Smear positive (+ve) TB were 14 percent $(n=12)$, Smear -ve were 11 percent $(n=10)$, Tubercular Pleural Effusion 13 percent $(n=11)$, Tubercular Lymphadenitis 42 percent $(n=37)$, Intestinal TB, Disseminated TB \& others were 19 percent(n=17).
Table-VIII

Tubercular status of patient's suspected for TB

\begin{tabular}{lc}
\hline Tubercular status & Percent (n) \\
\hline Smear +ve TB & $14(12)$ \\
Smear -ve TB & $11(10)$ \\
Tubercular pleural effusion & $13(11)$ \\
Tubercular lymphadenitis & $42(37)$ \\
Intestinal TB & $3(3)$ \\
disseminated TB & $8(7)$ \\
Others (Bone T3B/Spinal TB/ & $8(7)$ \\
Tubercular Meningitis/Miliary TB) & \\
\hline
\end{tabular}

In Table-IX symptoms of TB arrived more than 2 months back for 68 percent $(n=59)$, within 1-2 months 30 percent $(n=26)$ and less than 1 month 2.3 percent $(n=2)$. Most of the participant's duration of tuberculosis diagnosis was less than 2 months in 83 percent $(n=72)$ and treatment was started less than 1 month in 77 percent $(n=67)$.

Table-IX

Symptoms arrival duration, duration of diagnosis\& treatment duration of TB participants

\begin{tabular}{|c|c|c|}
\hline Duration & & Percent (n) \\
\hline$<1$ month & & $2.3(2)$ \\
\hline \multicolumn{3}{|c|}{ Symptoms Duration } \\
\hline 1-2months & & $30(26)$ \\
\hline$>2$ months & & $68(59)$ \\
\hline \multicolumn{3}{|c|}{ Duration of TB Diagnosis } \\
\hline$<2$ months & & $83(72)$ \\
\hline \multirow[t]{2}{*}{$>2$ months } & & $17(15)$ \\
\hline & not yet started & $6(5)$ \\
\hline Treatment & started $<1$ month & $77(67)$ \\
\hline Duration & started $>1$ month & $17(15)$ \\
\hline
\end{tabular}

Daily food intake of participant's is shown in Table10. Most of the participant takes more than three meals 54 percent $(n=47)$ participants. However, three meals were taken by 45 percent $(n=39)$ participants and two meals were taken only 1 percent $(n=1)$.

Table-X

Daily food intake of participant

\begin{tabular}{lc}
\hline Daily meal number & Percent (n) \\
\hline Two meal & $1(1)$ \\
Three meal & $45(39)$ \\
more than three meal & $54(47)$ \\
\hline
\end{tabular}


Nutritional status of participant is shown in Table XI. Most of the participants were participants. However, under-nutrition was present in 36 percent $(n=31)$ participants and over-nutrition were only 8 percent $(\mathrm{n}=7)$.

\section{Table-XI}

Nutritional status of TB patients before starting treatment

\begin{tabular}{lc}
\hline Nutritional status of TB participant & Percent (n) \\
(according to BMI) & \\
\hline Under-nutrition/malnutrition & $36(31)$ \\
Normal nutritional status & $56(49)$ \\
Over-nutrition & $8(7)$ \\
\hline
\end{tabular}

\section{Discussion}

This study was conducted to assess the nutritional status of TB patients who had attended at OPD and were admitted of Bangabandhu Sheikh Mujib Medical University. Malnutrition is frequently observed in patients with pulmonary TB though nomal nutritional status was more. Several studies reported that patients with active pulmonary TB are malnourished, as indicated by reductions in the level of macronutrient and micronutrient status ${ }^{14,15}$.

There is so many evidence which shows poor nutrition is a risk factor for developing TB $^{16}$ is result of the wide prevalence of malnutrition among newly diagnosed TB patients which also found in this study, consistent with findings from other studies. ${ }^{17-}$ $19,20,21$. So special attention should be needed for TB patients when distributing food within the family. Every TB patient need baseline nutritional assessment prior to the commencement of treatment. This would help in the planning of nutritional supplementation according to individual needs and habits.

Nutritional knowledge is essential, particularly for the improved management of patient nutrition and treatment. ${ }^{22}$ Like so many country lack of knowledge on nutrition is a common phenomenon in our country $^{23-25}$. Nutritional requirements of TB patients is therefore essential, and programme policy makers need to consider this issue. But not only knowledge or awareness could develop the scenario, sometimes poverty prevent the application process, which could observe in this study too. Education on nutrition alone will not sufficient if food price hikes ${ }^{26}$. To reduce long-term prevalence of TB infection, the underlying social determinants of under nutrition need to be addressed.

\section{Ethical Consideration}

Ethical permission of this study was taken from the Institutional Review Board (IRB) of BSMMU. The purpose and procedure of the study were properly explained to the patients and consent was taken. The study was not involving any additional burden to the participants. All participants in this research study had a right to have the information they provide to be kept confidential. Additionally, in order to conduct a research study, it is imperative to consider any harm that might occur to participants. Furthermore, the purpose of the study was clearly indicated to participants prior to the study being conducted. An informed consent section was included as the first page of the study.

\section{Conclusion}

Tuberculosis (TB) is a common communicable disease in Bangladesh. In this study almost 36\% participants of tuberculosis were in under-nutrition. So Nutrition supplementation could be needed in improving the disease condition to reduce further morbidity and mortality. On the other hand large scale study should be needed for taking proper steps to know the overall situation of the country.

\section{References}

1. Cegielski J P, McMurray D N. The relationship between malnutrition and tuberculosis: evidence from studies in humans and experimental animals. Int $\mathrm{J}$ Tuberc Lung Dis. 2004;8:286-298.

2. Metcalfe N. A study of tuberculosis, malnutrition and gender in Sri Lanka. Trans $\mathrm{R}$ Soc Trop Med Hyg. 2005;99:1 15-119.https://doi.org/10.1016/ j.trstmh.2004.06.007.PMid:15607338

3. Lettow M V, Harries A D, Kumwenda J J, et al. Micronutrient malnutrition and wasting in adults with pulmonary tuberculosis with and without HIV coinfection in Malawi. BMC Infec Dis. 2004;4:6168..https: / / doi.org/10.1186/1471-2334-461.PMid:15613232 PMCid:PMC544350

4. Zachariah R, Spielmann M P, Harries A D, Salaniponi F M. Moderate to severe malnutrition in patients with tuberculosis is a risk factor associated with early death. Trans R Soc Trop Med Hyg. 2002;96:291-294.https:// doi.org/10.1016/S0035-9203(02)90103-3

5. Muhammad F.,Chowdhury M.,Arifuzzaman M.,Chowdhury ABM. A,,Public Health Problems in Bangladesh: Issues and Challenges, South East Asia Journal of Public Health. 2016; 6(2):11-16.https:// doi.org/10.3329/seajph.v6i2.31830

6. World Health Organization. Global Tuberculosis Control. 2010. WHO: Geneva, Switzerland. World Health Organization. 
7. World Health Organization. Global tuberculosis report 2013. Geneva, WHO, 2013.

8. Zachariah R, Spielmann M P, Harries A D, Salaniponi F M. Moderate to severe malnutrition in participants with tuberculosis is a risk factor associated with early death. Trans R Soc Trop Med Hyg. 2002;96:291294.https://doi.org/10.1016/S0035-9203(02)901033

9. Onwubalili JK. Malnutrition among tuberculosis participants in Harrow, England. Eur J ClinNutr. 1988;42:363-366.

10. Kennedy N, Ramsay A, Uiso L, Gutmann J, Ngowi FI, et al. Nutritional status and weight gain in participants with pulmonary tuberculosis in Tanzania. Trans R Soc Trop Med Hyg. 1996;90:162-166.https://doi.org/ 10.1016/S0035-9203(96)90123-6

11. Gillespie SH, Kennedy N. Weight as a surrogate marker of treatment response in tuberculosis. Int $\mathrm{J}$ Tuberc Lung Dis. 1998;2:522-523.

12. Onwubalili JK: Malnutrition among tuberculosis patients in Harrow, England. Eur J Clin Nutr. 1988, 42: 363-366.

13. Saha K, Rao KN: Undernutrition in lepromatous leprosy. V. Severe nutritional deficit in lepromatous patients coinfected with pulmonary tuberculosis. Eur J Clin Nutr. 1989, 43: 117-128.

14. Onwubalili JK: Malnutrition among tuberculosis patients in Harrow, England. Eur J Clin Nutr. 1988, 42: 363-366.

15. Saha K, Rao KN: Undernutrition in lepromatous leprosy. V. Severe nutritional deficit in lepromatous patients coinfected with pulmonary tuberculosis. Eur J Clin Nutr. 1989, 43: 117-128.

16. Lönnroth K, Raviglione M. Global epidemiology of tuberculosis: prospects for control. Sem Res Crit Care Med. 2008;29:481-491.https://doi.org/10.1055/s0028-1085700.PMid:18810682

17. Metcalfe N. A study of tuberculosis, malnutrition and gender in Sri Lanka. Trans $\mathrm{R}$ Soc Trop Med Hyg. 2005;99:115-119..https://doi.org/10.1016/ j.trstmh.2004.06.007.PMid:15607338
18. Lettow M V, Harries A D, Kumwenda J J, et al. Micronutrient malnutrition and wasting in adults with pulmonary tuberculosis with and without HIV coinfection in Malawi. BMC Infec Dis. 2004;4:6168..https: / / doi.org/10.1186/1471-2334-461.PMid:15613232 PMCid:PMC544350

19. Zachariah R, Spielmann M P, Harries A D, Salaniponi F M. Moderate to severe malnutrition in patients with tuberculosis is a risk factor associated with early death. Trans R Soc Trop Med Hyg. 2002;96:291-294.https:/ / doi.org/ 10.1016/S0035-9203(02)90103-3

20. Dodor E A. Evaluation of nutritional status of new tuberculosis patients at the Effia-Nkwanta Regional Hospital. Ghana Med J. 2008;42:22-28.

21. Miller L G, Asch S M, Yu E I, Knowles L, Gelberg L, Davidson P. A population-based survey of tuberculosis symptoms: how atypical are atypical presentations? Clin Infect Dis. 2000;30:293-299.https://doi.org/10.1086/ 313651.PMid: 10671331

22. Wardle J, Parmenter K, Waller J. Nutrition knowledge and food intake. Appetite. 2000;34:269-72.https:// doi.org/ 10.1006/appe.1999.0311.PMid:10888290

23. Heaney S, O'Connor H, Micheal S, Gifford J, Naughton G. Nutrition knowledge in athletes: a systematic review. Int J Sport Nutr Excerc Metab. 2011;21:248-261. https://doi.org/10.1123/ijsnem.21.3.248

24. Alam N, Roy S K, Ahmed T, Ahmed A S M. Nutritional status, dietary intake, and relevant knowledge of adolescent girls in rural Bangladesh. J Health Popul Nutr. 2010;28:86-94.

https://doi.org/10.3329/jhpn.v28i1.4527.PMid:20214090 PMCid:PMC2975850

25. Choudhury N, Jalal C S B. Maternal nutritional knowledge and child nutritional status. In: Pasha A, editor. Pathways out of extreme poverty: findings from Round I Survey of CFPR Phase II. Dhaka, Bangladesh: BRAC; 2009. pp. 117-124.

26. Sulaiman M, Parveen M, Das N C. Impact of food hike price on nutritional status of women and children. Research Monograph Series 38. Dhaka, Bangladesh: BRAC; 2009. 